\title{
Elaboration, Collaboration, And Contribution Of Traditional Law In Indonesian National Legal System
}

\author{
Yohanes Firmansyah, Michelle Angelika S, Hanna Wijaya, Yana Sylvana \\ ${ }^{1}$ Faculty of Law, Pembangunan Nasional Veteran Jakarta University, Indonesia \\ Corresponding Author: ${ }^{*}$ yohanesfirmansyah28@gmail.com, \\ 2michelleangelika111@gmail.com, ${ }^{3}$ hannwijaya@yahoo.com, ${ }^{4}$ sylvanayana@gmail.com
}

Article

History:

Submit:

2021-02-01

Publish:

2021-03-05

\section{Abstract}

Indonesia uses customary Law as positive Law in the archipelago, is obeyed and implemented as a custom, from generation to generation respected by the community as a national tradition. As a rule of Law, Indonesia adheres to many legal systems at the same time that lives and develops in society, namely the civil law system and the customary law system. All these legal systems are complementary, harmonious, and romantic. As the original Law that grows and develops from community habits, Customary Law affects the process of law enforcement in Indonesia. The values contained in customary Law in Indonesia were used in the formation of jurisprudence in the Supreme Court. This paper will explain how customary Law, which has an "unwritten" character, can fill the Indonesian civil law system's legal gap. This paper's research method is a normative legal research method and uses several approaches, namely the statutory approach, the comparative approach, and the historical approach. This paper concludes that legal pluralism in Indonesia can be a solution to the legal gap created by the rigidity of civil law application.

Keywords: customary Law; legal system; civil Law; traditions and culture; history

Journal Homepage http://ijssr.net/index.php/ijssr

This is an Open Access article under the CC BY SA license

https://creativecommons.org/licenses/by-sa/4.0/

Published by Indonesian Academy of Social and Religious Research 


\section{Introduction}

In legal philosophy, one of the topics discussed is the purpose of Law. Gustav Radbruch, as one of the leading legal scholars from Germany, put forward the objectives of Law, which consist of three things: certainty, justice, and expediency. Initially, he stated that the goal of confidence was ranked first among the other objectives. However, after seeing the fact that Germany under Nazi rule legalized inhumane practices during World War II - by making laws legalizing the atrocities of war at that time -, Radbruch finally corrected his theory in over by placing the goal of justice above other purposes of Law. Justice is indeed the first and foremost goal of Law because it is under the Law itself's essence or ontology. That the Law is made to create order through fair regulations, namely the balance of conflicting interests so that everyone gets as much as possible what is his part. ${ }^{1}$ Throughout the history of the philosophy of Law, it can even be said that it has always given a special place to justice as an end of Law. ${ }^{2}$

If, philosophically, Law is primarily designed to create and provide justice for a country's people, then what happened in Indonesia still needs deep criticism. The direction of the development and development of Law in Indonesia is still confused, which logically has resulted in the law enforcement process (to provide and uphold justice for the people) in the space of the Indonesian Law System. Social justice (justice collectively and not justice according to individualistic needs) for all Indonesian people is still difficult to manifest in a real way by Indonesian Law; even the Law is felt to often play a role in the emergence of injustice phenomena, especially those that afflict the little people and groupsmarginalized society. Often in the Indonesian law stage, a group of people is deprived of their rights because of Law's rule as well as the controversy of Regional Regulation No. 8 of 2007 concerning Public Order, which was ratified by the DKI Jakarta Provincial Government some time ago, wherein the Regional Regulation, marginalized groups of people such as beggars, buskers, to hawkers are prohibited from carrying out their activities (begging, busking, and selling hawkers) on the grounds of disturbing public order. Even though the DKI Jakarta Provincial DPRD has approved this regional regulation, it still faces strong opposition from various parties because it is felt that it only has a normativelegalistic perspective but ignores the existing humanitarian aspects that those who are already marginalized in the socio-economic class will be increasingly

1 Van Apeldoorn, Inleiding Tot De Studie van Het Nederlandse Recht, 1st ed. (Jakarta: Pradnya Paramita, 1985).

2 Theo Huijbers, Filsafat Hukum Dalam Lintasan Sejarah, 1st ed. (Yogyakarta: Kanisius, 1982). 
marginalized again. ${ }^{3}$ In addition to the regional regulations regarding public order of the DKI Jakarta Provincial Government above, there are still several other regional regulations that are also considered controversial, such as the Regional Regulation on Public Order in several regions in Banten province, which has rules prohibiting women going out at night after certain hours so that they are considered gender bias discriminatory against women.

The Indonesian state, which affirms itself as a state based on Law as in Article 1 paragraph (3) of the 1945 Constitution of the Republic of Indonesia, also has a legal system. Interestingly, Indonesia adheres to three legal procedures at the same time that lives and develops in community and state life, namely the civil law system, the customary law system, and the Islamic legal system. The civil law system, which has the character of "written law," developed in Indonesia during the Dutch colonial period and has persisted until now to influence current legal products. Even though the colonial period ended 72 years ago, its seeds can still be felt today, considering that several Dutch colonial civil law products still exist and apply. In the field of criminal Law, Wetboek van Strafrechts (WvS) is still valid through Law No.1 of 1947 as a guideline in the criminal field (Criminal Code). In the civil sector, the Burgerlijke Wetboek (BW) of the Civil Code and the Wetboek Van Kopenhandel $(\mathrm{WvK})$ or the Commercial Code are still valid. Meanwhile, in the field of civil procedures, Herzien Inlandsch Reglement (HIR), Rechtsreglement Voor de Buitengewesten (RBg), and Reglement op de Burgerlijke Rechtsvordering (RR) are also still in effect and have not changed.

Besides, as the original Law that grows and develops from the customs of the community, customary Law greatly influences the process of law enforcement in Indonesia, and this customary Law is very diverse in Indonesia. In general, implementation will face obstacles, but it is quite efficient for the local community that enforces it. If it is calculated, more people obey and obey customary Law than state law. Cornelis van Vollenhoven as the first expert who initiated the division of customary Law classified 23 customary environments in the archipelago, namely: Aceh, Gayo and Batak, Nias and its surroundings, Minangkabau, Mentawai, South Sumatra, Enggano, Melayu, Bangka and Belitung, Kalimantan (Dayak), Sangihe-Talaud, Gorontalo, Toraja, South Sulawesi (Bugis / Makassar), North Maluku, Maluku Ambon, Southeast Maluku, Papua, Nusa Tenggara, and Timor, Bali and Lombok, Java and Madura (Coastal Java), Mataraman Java, and West Java (Sunda). Meanwhile, according to Gertz, Americans state that Indonesians

3 Kompas, "Warga Miskin Tolak Raperda Ketertiban Umum," Kompas, September 11, 2007. 
have 350 cultures, 250 languages and all beliefs and religions in the world are in Indonesia.

This paper will examine the position, existence, and construction of customary Law in the legal system in Indonesia, which will be limited by the following problem formulations: (1) The historical journey of customary Law in Indonesia from time to time; (2) Continental legal system and customary Law in Indonesia; (3) The existence of customary Law in the legal system in Indonesia; (4) The complexity of recognizing customary Law as living Law in Indonesia; (5) Customary Law as the ontology of Indonesian legal development

\section{Methods}

This research is legal research with a prescriptive normative legal method. According to Peter Mahmud Marzuki, in legal analysis, several research approaches are generally known, namely: statute approach, conceptual approach, case approach, comparative approach, and historical approach. This paper uses a statute approach, a comparative approach, and a historical approach. ${ }^{4}$

The statute approach is carried out by examining all laws and regulations related to the issue being studied, namely statutes and regulations relating to the customary law system and Islamic Law. The historical approach is related to the historical legal system in Indonesia. Meanwhile, the comparative approach is carried out by comparing the civil legal system, customary law system, and the Islamic legal system in Indonesia.

\section{Result and Discussion}

\section{TRAVEL HISTORY OFTRADITIONAL LAW IN INDONESIA FROM TIMETOTIME}

Customary Law that lives grows and develops in Indonesia by the times, flexible according to the values of Pancasila as stated in the Preamble of the 1945 Constitution (UUD 1945). ${ }^{5}$ The 1945 Constitution only creates ideas that cover the mystical atmosphere of the 1945 Constitution. These basic thoughts animate the ideals of Law surrounding both written and unwritten state law. In

4 Mahmud Marzuki dan Peter Mahmud, "Penelitian Hukum," Jurnal Penelitian Hukum, 2011; Muhammad Abdul Kadir, "Hukum Dan Penelitian Hukum.," Bandung: PT. Citra Aditya Bakti., 2015; Soerjono Soekanto and Sri Mamudji, Penelitian Hukum Normatif, Suatu Tinjauan Singkat, Jakarta: Raja Grafindo Persada, 2011.

5 Satjipto Rahardjo, Sisi-Sisi Lain Dari Hukum Di Indonesia, 1st ed. (Jakarta: Kompas, 2003). 
the Preamble to the 1945 Constitution, the main points of thought that animate the realization of the country's basic Law's ideals is Pancasila. The affirmation of Pancasila as a source of the legal order is very meaningful for customary Law because customary Law is rooted in people's culture to manifest a real and living legal feeling among the people and reflect the personality of the people and nation of Indonesia. ${ }^{6}$ Thus, customary Law is philosophically a law that applies according to Pancasila as a way of life or the Indonesian nation's philosophy of life.

Evidence that before the foreigners entered Indonesia there was already customary law are as follows: 1) In 1000, in the Hindu era, King Dharmawangsa from East Java with his book called Civacasana; 2) Years 1331-1364, Gajah Mada Patih Majapahit, made a book called the Gajah Mada Book; 3) Years 1413-1430, Kanaka Patih Majapahit, wrote the Adigama book; 4) In 1350, Bali found the Kutaramanava law book. Many factors influence the development of customary law, apart from the progress of the times, science and technology, natural conditions, as well as traditional factors, as follows: 1) Magic and Animism; 2) Religious Factors; 3) Higher Power factor; 4) The existence of foreign powers. ${ }^{7}$

Hinduism only influences the islands of Java, Sumatra, and Bali. In other areas, it has been influenced by the "Malaio Polynesia" era, namely: An era where our ancestors still adhered to original customs influenced by the supernatural powers. During the Hindu era, several kingdoms grew, influenced by Hindu religious Law and Buddhist Law brought by traders (mostly from China). These kingdoms included:1) Sriwijaya, Raja Syailendra (7th to 9th century); 2) Medang (Mataram); 3) Zaman Singosari (Tumapel), founded by Ken Arok (Rajasa); 4) Majapahit era, based by Jayakatong (Jayakatwang). In this era where the existing kingdoms were influenced by Hinduism and a small part of Buddhism. It can be seen that there are caste divisions in the government and justice sectors. ${ }^{8}$

The Islamic era influenced the area: ${ }^{9}$

1) Aceh (Kingdom of Pasai and Perlak), the influence of Islamic Law is quite strong on customary Law, and it can be seen from each settlement

6 Anthon Freddy Susanto, Semiotika Hukum, Dekontruksi Teks Menuju Progresifitras Makna, 1st ed. (Bandung: Refika Aditama, 2007).

7 Zaka Firma Aditya, "Romantisme Sistem Hukum Di Indonesia : Kajian Atas Konstribusi Hukum Adat Dan Hukum Islam Terhadap Pembangunan Hukum Di Indonesia," Jurnal Rechts Vinding: Media Pembinaan Hukum Nasional 8, no. 1 (2019): 37, https://doi.org/10.33331/rechtsvinding.v8i1.305.

8 Soerjono Soekanto, Masalah Kedudukan Dan Peranan Hukum Adat, 1st ed. (Jakarta: Academica, 1979).

9 Ratno Lukito, Pergumulan Antara Hukum Islam Dan Adat Di Indonesia, 1st ed. (Jakarta: INIS, 1998). 
place led by a religious scholar who acts as an imam and has the title “Teuku / Tengku”;

2) Minangkabau and Batak, customary Law, is still surviving in daily life, while Islamic Law plays a role in religious life, in this case, it is seen in the field of marriage;

3) South Sumatra (Palembang / Kukang), during the "Ratu Senuhun Seding" period, customary Law was recorded in Malay Arabic, namely the existence of the Simbur Cahaya Law. In it contains terms derived from Islamic Law, such as Khatib Bilal;

4) Lampung, the entry of Islam here during the "Ratu Pugung" era where his daughter named "Sinar Alam" married "Syarif Hidayat Fatahillah / Sunan Gunung Jati," after the fall of Sunda Kelapa into the hands of Islam. The kinship structure adopted is the male lineage (patrilineal). Where is the oldest male (called "pun," which is appreciated), Majorate Inheritance. He has the right and obligation to continue the parent

5) Java, consisting of East Java, Central Java, West Java, Banten, and Kalapa (Sunda Kelapa);

6) In Bali, the influence of Islam is very small. The community still maintains the customs of Hinduism. The relationship between adat / customary Law and religion (especially Hinduism) in Bali is an exception. This is reinforced by the affirmation of the Bali Regional Government, which states that the definition of adat in Bali with its village and customary manners is different from the definition of adat in general.;

7) Kalimantan, Islam has only succeeded in influencing communities in coastal areas and people in rural areas still based on beliefs from the Malaio Polynesian era or kaharingan beliefs; and

8) Sulawesi, starting with the establishment of the kingdom of "Goa" by Datuk Ri Bandang. The influence of Islam is only a spiritual filler; it does not change/urge community customs.

\section{CONTINENTAL AND TRADITIONAL LAW SYSTEMS IN INDONESIA}

In its history, the Indonesian legal system is a legacy from the Dutch colonial (European Kontnental / civil Law) that once controlled Indonesia for more than 350 years. The Dutch legal system is also applied in Indonesia based on 
the concordat principle. ${ }^{10}$ According to Andi Hamzah, the Dutch legal system's influence also affects judges' decisions, where judges in Indonesia, in examining, hearing, and deciding cases, including those concerning the problem of legal discovery, are influenced by the civil law system. ${ }^{11}$ While the main characteristics of civil Law are the existence of codification or accounting of laws or laws in a book (code). ${ }^{12}$

Indonesia itself has submitted itself to adhering to a civil legal system so that the main principle is to deposit the Law in written rules or outlined in the document of laws. Unwritten Law is not recognized as Law, nor are regulations made other than by the state and are not referred to as Law but as public morals. However, this civil law system in practice has many weaknesses because of its written nature. It is not flexible in keeping up with society's development, tends to be rigid and static.

Normalization in the form of written rules can be a form of limitation on something abstract in nature or a restriction in a material and dynamic context, or a limitation in the time dimension. Therefore, society's value consciousness into laws will logically bring about the substance of the laws being left behind. ${ }^{13}$ Besides, many western laws and regulations have been adopted into Indonesia and enforced in Indonesia, such as the Criminal Code (KUHP), the Civil Code (KUHP), the Commercial Code (KUHD). , thus the phenomenon of legal gab or the separation of the values of Indonesian society from the values of laws and regulations is a fundamental issue, and substantially Indonesian Law will always be a continuation that is difficult to avoid. ${ }^{14}$

As Montesquieu said, the civil law system also makes judges as mouthpieces for the Law, meaning that judges only enforce the law as written in the Law. This civil legal system follows the legal positivism philosophy that states that Law's primary goal is legal certainty, not justice and/or benefit because positivism philosophy prioritizes things that are clear and definite (positive) above all by arguing that only something is particular. which can be used as a measure of truth. Thus, in the civil law system's culture, Law is synonymous with Law, the

10 Ansori Ahmad, Sejarah Dan Kedudukan BW Di Indonesia, 1st ed. ((Jakarta: Rajawali, 1986).

11 Andi Hamzah, Asas-Asas Hukum Pidana, 1st ed. (Jakarta: PT. Rinek Cipta, 2010).

12 Wirjono Prodjodikoro, Tindak-Tindak Pidana Tertentu Di Indonesia, 1st ed. (Bandung: PT Refika Aditama, 2008).

13 H. Mustaghfirin, "Sistem Hukum Barat, Sistem Hukum Adat, Dan Sistem Hukum Islam Menuju Sebagai Sistem Hukum Nasional Sebuah Ide Yang Harmoni," Jurnal Dinamika Hukum, 11, no. 1 (2011): 92.

14 H. Mustaghfirin. 
source of Law is Law, values come from Law; therefore, the civil law system does not recognize the laws and values that live in Public.

Legal gaps that exist in society can be overcome by using an unwritten legal system. There are two unwritten legal systems in Indonesia, namely the customary law system and the Islamic legal system. ${ }^{15}$ Esin Orucu, in his writing entitled What is a Mixed Legal System: Exclusion or Expansion, believes that no country purely adheres to civil Law or standard law systems. Therefore, it is unavoidable to combine two or more legal systems in today's modern legal state. Orucu further explained that several legal systems could mix due to international relations and significantly impact the legal system in every country. ${ }^{16}$

This hybrid legal system is a classic development and classification of a legal system. There are several examples of mixing legal systems and mention simple mixes between civil law and common law legal systems and complex mixes between the two legal systems and religious Law or customary Law. In Indonesia, an Islamic legal system and customary Law can overcome the gaps in adopting a civil legal approach.

\section{TRADITIONAL LAW EXISTENCE IN THE LEGAL SYSTEM IN INDONESIA}

Mason C. Hoadley, in his writing The Leiden Legacy: Concepts of Law in Indonesia (Review), Mason C. Hoadley argues that the existence of customary Law as the living Law of the Indonesian nation is increasingly marginalized. 17 Customary Law, which initially became a living or developing Law and provided solutions to various problems in the life of the Indonesian people, is losing its existence. At present, if we look at the empirical facts in society, various complex issues faced by indigenous peoples in Indonesia can be found, especially when customary Law is faced with positive Law. For example, when society's traditional rights are confronted with investors' interests through state legal means. The development of the Indonesian Legal System tends to prefer the civil legal system model from western countries and Indonesian law politics, leading

15 Ahmad Rofiq, Pembaharuan Hukum Islam Di Indonesia, 1st ed. (Yogyakarta: Gema Medua, 2001).

16 Erin Orucu, "What Is a Mixed Legal System: Exclusion or Expansion," What Is a Mixed Legal System: Exclusion or Expansion 12, no. 1 (2008): 2.

17 M. Yahdi Salampessy, “The Leiden Legacy: Concepts of Law in Indonesia," Indonesia Law Review 4, no. 3 (December 1,2014): 385, https://doi.org/10.15742/ilrev.v4n3.123. 
to the codification and unification of Law, accelerating the loss of customary law and its institutions. ${ }^{18}$

The loss of customary Law as a source of Law in Indonesia is due to the assumption that customary Law is very traditional, dated, and ancient, not to reach modern times. The implications of Indonesian law politics can solve problems in society that tend to ignore customary Law and prioritize state law, even though it is more relevant than using state law. The number of horizontal conflicts between indigenous peoples in one area should be resolved through indigenous peoples' settlement institutions' role. ${ }^{19}$ A crucial problem that arises in everyday life is the difference in perceptions between land tenure by the community based on customary rights and general interests, which are the state's burden and obligation. ${ }^{20}$ Another example is the idea that the basis for the conviction of an act should be extended to the realm of customary law values. ${ }^{21}$

If you look at its historical legalism, the enactment of Law in Indonesia notes that many legal experts, especially from Western countries, tend to study customary Law as a law that has lived in Indonesian society for thousands of years. Snouck Hurgronje, the first expert to study Indonesian Law, wrote a book entitled De Atjehers, which mentions customary Law as customary recht to give a name to a system of social control that lives in Indonesian society. Furthermore, the theory of Snouck Hurgronje was developed by Cornelis van Vollenhoven who became known as an expert on customary Law in the Dutch East Indies.

Considering that customary Law is a law that reflects the personality and spirit of the nation, it is believed that some customary law institutions are still relevant as material in shaping the Indonesian legal system. ${ }^{22}$ Customary Law,

18 M Syamsudi, “Beban Masyarakat Adat Menghadapi Hukum Negara," Jurnal Hukum 15, no. 3 (2008): 338-51.

19 Jacoba Sahalessy, "PERAN LATUPATI SEBAGAI LEMBAGA HUKUM ADAT DALAM PENYELESAIAN KONFLIK ANTAR NEGERI DI KECAMATAN LEIHITU PROPINSI MALUKU," SASI 17, no. 3 (September 30, 2011): 45, https://doi.org/10.47268/sasi.v17i3.364.order and peace is a basic requirement in the life of a people a very close relationship with law enforcement process. Process of law enforcement in the area of customary law community unit as in the countries of the Moluccas should be understood as a unit which can't be separated from their culture. Role of Institutions Latupati be one of the institution of customary law (adat institution

20 Rosmidah Rosmidah, "Pengakuan Hukum, Hak Ulayat, Masyarakat Hukum Adat, Hambatan, Implementasinya.," Inovatif, Jurnal Ilmu Hukum 2, no. 4 (2010).

21 Reimon Supusesa, "Eksistensi Hukum Delik Adat Dalam Perspektif Pembaharuan Hukum Pidana Di Maluku Tengah," Mimbar Hukum 24, no. 1 (2012): 41-54, https://doi.org/10.22146/jmh.16148.

22 Ratna Winahyu Lestari Dewi, "PERANAN HUKUM ADAT DALAM PEMBANGUNAN DAN PEMBENTUKAN KITAB UNDANG-UNDANG HUKUM PIDANA NASIONAL," Perspektif 10, no. 3 (July 29, 2005): 265, https://doi.org/10.30742/perspektif.v10i3.271. 
which can no longer be maintained, will become extinct over time, by the flexible and dynamic nature of customary Law (not static). According to Von Savigny, as quoted by Soepomo, Customary Law is a living law because it manifests the real feelings of Law from the people. According to its terms, customary Law is continually in a state of growth and development like life itself. Agreeing with Savigny, van Vollenhoven said that customary Law has had a slightly different content in the past, customary Law has shown progress. Furthermore, Vollenhoven emphasized that customary Law is developing and moving forward; customary decisions give rise to customary Law

If the enactment of a law is contrary to the values and legal norms that live and apply in society, of course, it will be rejected. In the Indonesian context, the living Law of Indonesian society is Adat law. Customary Law can also be used as a source of Law by judges if the Law so dictates. ${ }^{23}$ Customary Law is a law that is not codified among Indonesians and foreigners of the East (including Chinese and Arabic).

Meanwhile, to analyze the position of customary law in the legal system, it is necessary to show one of the natural streams of legal science: Sociological Jurisprudence delivered by Eugen Ehrlich. Ehrlich's basic conception of Law is what is called living Law. Excellent and effective positive Law is the Law by the living Law of society that reflects the values in it.

Ehrlich's message to legislators is in making laws that live in society. It is a fact and cannot be denied that the customary laws that apply in Indonesia in general and Aceh Province, in particular, are laws that are by the values that live in society. Therefore, for customary Law to be effective in the community, in the formation of laws and qanuns in Aceh, people's representatives who sit in legislative institutions must explore and accommodate legal awareness. Public legal awareness that has been formalized in both laws and qanuns will be used as the basis for maintaining order and harmony in the community's life.

\section{COMPLEXITY OF TRADITIONAL LAW OR CUSTOMARY LAW RECOGNITION AS LAW IN INDONESIA}

The Dutch colonial government officially recognized customary Law as the original Law of Indonesia. It was parallel to European Law through Article 131

23 Sulatriyono, "Penerapan Norma Dan Asas-Asas Hukum Adat Dalam Praktik Peradilan Perdata," Mimbar Hukum - Fakultas Hukum Universitas Gadjab Mada 24, no. 1 (2012): 25-40, https://doi. org/10.22146/jmh.16147. 
paragraph (6) IS, which states, "Indonesian law is positive law for the Indonesian nation." The meaning of Indonesian Law in this article is customary Law. Article 131 paragraph (6) is a legal umbrella for the recognition of the Dutch East Indies Government towards customary Law and at the same time recognition of customary Law as positive Law that lives for the Indonesian people. The recognition of customary Law as positive Law, during the reign of the Dutch East Indies, there were two legal systems in effect, namely the Dutch legal system for Europeans and for foreign Easterners and Indonesians who subjected themselves to it European Law was enforced (Article 131 paragraph (2) IS ) and customary Law for the Indonesian nation and foreign easterners who are no strangers to Indonesia (Article 136 paragraph (6) IS).

Post-Independence, recognition of unwritten Law is only explained or included in the General Explanation of the 1945 Constitution number I, which states “... The Basic Law is a written basic law. In addition to the Basic Law, a basic unwritten law also applies namely basic rules that arise and are maintained in state administration practice even though they are not written down". Furthermore, Article 18B paragraph (2) of the Amendment of the 1945 Constitution states, "The State recognizes and respects indigenous peoples and their traditional rights as long as they are still alive and by the development of society and the principles of the Unitary State of the Republic of Indonesia, which are regulated in Law." According to this article, the recognized customary Law is customary Law that is still real, clear on the orthodox community's material and scope.

The provisions of Article 18B paragraph (2) above can be understood that the 1945 Constitution prioritizes written Law over unwritten Law. The recognition of customary Law that is still alive in the community in an area must be carried out by statutory regulations (written) and by the principles of the Unitary State of the Republic of Indonesia. The Constitutional Court strengthened this through Decision Number 31 / PUU-V / 2007 concerning the Review of Law 31 of 2007 concerning the Establishment of the City of Tual in Maluku Province. In this decision, the Constitutional Court determined four conditions for the constitutionality of customary law community units in Article 18B paragraph (2) of the 1945 Constitution, namely: (1) still alive; (2) by the development of society; (3) by the principles of the Republic of Indonesia; (4) regulated in Law. If this requirement is not fulfilled, indigenous peoples cannot become litigants at the Constitutional Court because they do not have legal standing. ${ }^{24}$

24 Zaka Aditya and Sholahuddin Al-Fatih, "STATE LIABILITY FOR VIOLATION OF CONSTITUTIONAL RIGHTS AGAINST INDIGENOUS PEOPLE IN FREEDOM OF RELIGION 
In consideration of Decision Number 31 / PUU-V / 2007, the Constitutional Court emphasized that "... recognition of the existence of indigenous peoples as rights holders or as legal subjects is a fundamental right. The essential and fundamental thing is that the customary law community is constitutionally recognized and respected as rights holders, which of course can also be burdened by Law in a society that has been state, so the customary law community must receive attention as other legal subjects when the Law wants to regulate, especially arrange in the context of allocating the sources of life. "The provisions of Article 18B paragraph (2) of the 1945 Constitution and Decision Number 31 / PUU-V / 2007 do normatively acknowledge the existence of customary law, but on the other hand also impose restrictions on orthodox communities and which the country can recognize customary laws.

\section{TRADITIONAL LAW OR CUSTOMARY LAW AS THE ONTOLOGY OF INDONESIAN LEGAL DEVELOPMENT}

In addition to the two main points of thought in the Civil Law System which have problems in them so that they trigger issues in the process of developing Indonesian Law as described above, there is also an undeniable fact that the Civil Law System is a modern legal system applied by Indonesia today. is not a native Indonesian legal system. Civil Law System is a legal system resulting from the transplantation of foreign powers into Indonesian soil through the Dutch government's colonialism practice in the archipelago. The Civil Law System is a legal system with a history of mainland European civilization from the Roman rule era by Emperor Justinian in the 5th century AD until Napoleon Bonaparte. $\mathrm{He}$ annexed almost the entire territory of mainland Europe in the early 19th century. ${ }^{25}$ Thus, the Civil Law System is a legal system based on philosophy, thinking paradigm, and Western European civilization's characteristics, which is why it is not a legal system based on philosophy, thinking paradigm, and the Indonesian people's original characteristics.

On the other hand, before the colonialism era, the archipelago was not a sociological area without Law. In various regions in this archipelago, there have

AND BELIEF," Brawijaya Law Journal 4, no. 1 (March 31, 2017): 29-58, https://doi.org/10.21776/ ub.blj.2017.004.01.02.

25 James G Apple and Robert P. Deyling, "A Primer on the Civil Law System," in Federal Juducial Centre and International Judicial Relation Committee of Judicial Confrence of United State (United State: Federal Juducial Centre and International Judicial Relation Committee of Judicial Confrence of United State, 2000), 1 . 
been organized units of society managed by a traditional value system and trusted from generation to generation. The value system that lives in a society that manages the order between them is what Snouck Hurgronje - when he wrote a book about Acehnese culture entitled De Atjehers - is called Adatrecht or what is later commonly translated as Customary Law.

Customary Law originates from the norms of everyday life, which immediately emerges as a statement of the culture of the indigenous Indonesians, in this case as a statement of a sense of justice in a selfish relationship. ${ }^{26}$ Customary Law is the original Law of the Indonesian nation, which the Indonesian people made from generation to generation based on their value consciousness, which is manifested in daily life habits using a measure of their reasoning and sense of justice. Thus, if we return to Von Savigny's thought that Law reflects the people's soul, then customary Law is a reflection of the soul of the Indonesian people.

This matter will be made clearer by looking at the characteristics of customary law. Customary Law has the following features and characteristics ${ }^{27}$

- Communalistic, meaning that humans according to customary Law are creatures in close social bonds.

- Religio-magis, meaning that customary Law is always related to magical matters and spiritualism (belief in ancestral spirits, etc.).

- Concrete, meaning that the living relationships that exist in customary Law are concrete or real relationships. Likewise, in customary Law, the terms buying and selling are only interpreted in a real way; that is, if there is a real exchange of money and goods in cash, in customary Law, there is no known credit trading system known in BW.

- Visual, meaning that in customary Law, legal relations are considered to occur only because they are determined by a visible bond (such as the peningset system, etc.).

The characteristics of customary law, as stated above, are a reflection of the character of Indonesian society. The communalistic nature can be seen from the habits of cooperation and fall-mountain activities, which are usually carried out in the face of great work together, or in the deliberation mechanism that has been used by our society since centuries ago in solving a common problem. The religious-magical nature can be seen from our society's habits, such as the giving

26 Surojo Wignjodipuro, "Pengantar Dan Asas-Asas Hukum Adat," in Hukum Adat, 1st ed. (Bandung: Alumni, 1979), 7.

27 Wignjodipuro. 
of offerings, salvation ceremonies, earth alms, and so on. This is done because our community does not differentiate between the outer and the unseen dimensions. The two dimensions are believed to be an interrelated unity so that all kinds of actions that will be carried out for the sake of the born world's life also always pay attention to aspects of the unseen world's energy. Concrete and visual properties can be seen in people's daily habits, as exemplified in the description of these two characteristics above. The characteristics of the indigenous people of Indonesia that are reflected in the style and nature of customary Law above are the original legal philosophy of the Indonesian people, which can be said to be a marker for the spirit of the Indonesian nation so that it automatically functions as a differentiator from other philosophies and legal systems outside of it such as the system western Law. This will be further proven if a direct comparison is made between the customary law system and the western legal system. According to Soerojo, at least three main points show the difference between the western legal system and the customary law system. First, the western legal system recognizes the distinction between zakelijk rechten and persoonlijk rechten, while the traditional law system does not recognize such differentiation of rights. Rights under the customary law system are determined according to the context of the situation. Second, there is no legal classification or fielding like the dichotomy in the customary law system, according to Ulpianus adopted in the western legal system, which divides the legal space into two, namely public Law and private Law. Third, suppose there is a distinction between violations of the Law into violations of criminal Law and violations of civil Law in the western legal system, then in the customary law system. In that case, there is no distinction between violations of the Law as such. There is only one violation of the Law in the customary law system, namely the so-called customary offense. The difference in concept between the western legal system and the traditional law system above is due to the difference in the view of life (legal philosophy) or the nation's soul that is the background of the two legal systems. Suppose in the western world, the existing outlook on life is liberalistic, rational, and intellectualistic. In that case, the traditional view (the original view of the Indonesian people) is cosmic (it does not separate the world of birth and the occult world). ${ }^{28}$

In the western view, the first and foremost subject is the individual so that society is seen as the sum (collection) of individuals. This view is a direct result of a liberalistic view so that individual freedom gets the highest priority of protection.

28 Wignjodipuro. 
Whereas in the traditional view, which is communalism, individuals are seen as part of society so that society is the first subject in Law whose interests must be placed above all else because it is believed that if the interests of society have been fulfilled, then individual interests will automatically be fulfilled considering the individual. is part of the community. ${ }^{29}$ So from the Explanation above, it seems clear that customary Law is a manifestation of value consciousness and the characteristics of Indonesian society that distinguish it from other legal systems so that it functions as the manifestation of original Law and a reflection of the nation's soul and the sense of justice of the Indonesian people. With the position of customary Law as the embodiment of original Law and a reflection of the nation's soul and the sense of justice of the Indonesian people, customary Law should have a central role in the development of Indonesian Law. ${ }^{30}$

Referring to Hans Kelsen's Stufen theory, the hierarchy of a legal rule culminates in the most basic and most abstract and meta-juridical legal regulations known as grundnorm, while the legal substance contained in the grundnorm is not in the form of regulations but abstract values, which is philosophical or in other words the philosophy of Law that animates all the existing legal rules under it. From this concept, it is not wrong if the Preamble of the 1945 Constitution as a further normative elaboration of Pancasila is categorized as a grundnorm in paralleling the Stufen theorie concept from Hans Kelsen above to the hierarchical structure of the Indonesian Legal System. Suppose you look further at the "General" Explanation of the 1945 Constitution section III. In that case, the Preamble position to the 45 Constitution is an elaboration of the main ideas that embody legal ideals (rechtsidee) that controls the country's fundamental laws. The Explanation of the 1945 Constitution regarding the Preamble position of the 45 Constitution indeed confirms that the Preamble of the 45 Constitution is a Grundnorm in the hierarchy of the Indonesian Legal System so that it functions as a wellborn (source of Law) of the National Legal System. Rechtsidee is the unification of values that play a role in people's lives influenced by the philosophy of life that is believed by the community, so that if the Preamble of the 1945 Constitution contains the main ideas that embody our national rechtsidee, then the main points of thought in the Preamble of the 1945 Constitution are the embodiment of the values. -the original values of the Indonesian people. In other words, the Preamble of the 45 Constitution as a grundnorm in the hierarchy of

29 Moh Koesnoe, Hukum Adat Sebagai Suatu Model Hukum, 1st ed. (Bandung: Mandar Maju, 1992).

30 Moh Koesnoe, Hukum Adat, Dalam Alam Kemerdekaan Nasional Dan Persoalan Menghadapi Era Globalisasi, 1st ed. (Surabaya: Ubhara Press, 1996). 
the Indonesian Legal System is an elaboration of the Customary values of the Indonesian nation. ${ }^{31}$ This will be further strengthened if there is an examination of the main points of thought in the Preamble to the 1945 Constitution, as explained by the "General" explanation of the 1945 Constitution part II. In the "General" Elucidation of the 1945 Constitution, part II, the four main ideas contained in the Preamble of the 1945 Constitution are elaborated, especially in the 4th or last paragraph. In brief, the points of thought are: First, the Indonesian state's form is a united state. Second, the establishment of the Indonesian state is to realize social justice for all people. Third, the Indonesian state system is based on the people's sovereignty and based on representative deliberation. Fourth, Indonesia's state is a country based on the only Godhead according to the basis of just and civilized humanity. The four things above, which are none other than the main points of thought in Pancasila, are the main ideas contained in the Preamble to the 1945 Constitution, which clearly describe and reflect the characteristics and features of the indigenous Indonesian people, which are also the features and characteristics of Customary Law Indonesian society. A state based on the only Godhead reflects the religio-magistic nature of Indonesian culture, namely those that believe in the existence of metaphysical-transcendental powers outside of themselves that encompass and control all aspects of their life. The main ideas about a united state, the goal of realizing social justice, and a state system based on people's sovereignty and representative deliberation reflect the communalistic and kinship character in Indonesian society. Even in the Explanation of "General" part II point 3, the main idea of a state system based on people's sovereignty and a system of representative deliberation is by the nature of Indonesian society. ${ }^{32}$

The description above clearly emphasizes the central juridical position of customary law in the National Law System, that customary law is the basis for the National Legal System. At the same time, customary Law is a grundnorm in the Indonesian Legal System. It is customary Law - as described in the Preamble to the 1945 Constitution - which functions as a source of Law or wellborn of every positive legal rule. Customary Law is the raw material for the substance of positive Indonesian Law. Every positive rule of Law must be compounded

31 Shidarta, "Karakteristik Penalaran Hukum Dalam Konteks Indonesia" (Universitas Parahyangan, 2004).

32 Kemenristekdikti, “Undang-Undang Dasar Republik Indonesia 1945," Resntra Kemenristekdikti 20152019, 2015. 
with its rechtsidee ${ }^{33}$. Customary Law serves as a touchstone for the substantive validity of all positive legal rules in Indonesia.

With the juridical-normative, philosophical, and sociological position of customary Law which occupies a central role in the Indonesian Legal System, namely as a source of Law (Welborn) and raw material in the formation of Indonesian Law as well as as the basis for the development and development of Indonesian Law as a whole. It can be ascertained that the existence of the legal gap phenomenon as the basis for the substantive problems of Indonesian Law will automatically be resolved, because the laws that will be developed are directly substantiated from the values that live in society. Thus the Law will always be linear with the demands of justice for the whole community.

If juridical-normative, philosophical, and sociological studies have shown the central position of customary law as the basis for the Indonesian legal system as described above, then what has happened to this day that results in all complex problems in the space for the development of Indonesian Law is a neglect of legal ontology. Indonesia. Indonesian Law is built precisely in the culture of the Civil Law System by involving all legal concepts and rechtsidee in it, all of which are a reflection and an explanation of the philosophy of life of a western society, which is foreign and contrary to the philosophy of life, rechtsidee, and legal concepts. The original Indonesian nation - while still paying attention to all the limitations of existing resources but by not making it a barrier in legal development efforts that genuinely reflect the National Legal Order features - is legal development that is uprooted from its original essence. In other words, all the problems that arise in the space for the growth and development of Indonesian Law are the fruit of "the alienation of Indonesian law."

Departing from this critical awareness, the offer and discourse to return to customary Law as the ontology of development and the development of Indonesian Law is a logical, essential, and solution offer so that it is a necessity in the goal of creating Indonesian Law that can provide justice for people of Indonesia. Customary Law is a legal system that is entirely different from the Civil Law System. Customary Law is non-statutory Law or unwritten Law ${ }^{34}$ because it manifests in society's everyday life habits. The existence of this feature is due to the belief in our community that what is written as a form of formulation

\footnotetext{
33 Koesnoe, Hukum Adat Sebagai Suatu Model Hukum; Koesnoe, Hukum Adat, Dalam Alam Kemerdekaan Nasional Dan Persoalan Menghadapi Era Globalisasi.

34 Wignjodipuro, "Pengantar Dan Asas-Asas Hukum Adat."
} 
can easily lead to misunderstanding because our society has long been aware that what is stated in the word will always show things that are not entirely precise about what is contained. in the bottom line. With this non-statutory customary law style, it can automatically be illustrated that customary Law does not recognize the principles of legism or positivism philosophy as contained in the Civil Law System. With the non-statutory pattern, which is a contrario of the principle of legism, customary Law is free from limitations and statism, which is a consequence of the form of written Law. Thus customary Law always has a dynamic character because customary Law is living Law to grow and develop along with the community's cultural dynamism. Besides that, the philosophy of positivism is not recognized in customary Law.

On the other hand, metaphysical things - which in positivism philosophy are categorized as things that cannot be used as a measure of truth because they are not certain - actually get a significant position in customary Law. This can be seen from the religio-magistic pattern in customary Law, which is also Indonesian society's pattern. The cosmic balance, which is the unity of the inner and outer world order, is the goal that the regulation in customary Law wants to target. Thus, the development and enforcement of the Law are not only limited to fulfilling the demands of "justice," which has been reduced to "what has been according to the law," but is for the sake of maintaining a cosmic balance based on the sense of justice that develops in society. Customary Law avoids the narrow certainty that legal positivism is prioritized in the Civil Law System culture because everything according to customary Law cannot be equated but must be studied and considered according to place, time, and circumstances (deso, kolo, Potro). ${ }^{35}$ With this flexibility, the difficulty in always being able to fulfill the demands of justice due to the tendency of conflicts between the objectives of justice and certainty (which in the culture of the Civil Law System and legal positivism tends to be prioritized for certainty) will certainly not be met so that it can be clearly stated. That customary Law will always be linear with the aim of justice.

\section{Conclussion}

Thus, the description above shows that the offer to return to the ontology of Indonesian Law, namely customary Law, is a critical, solution, and reasonable

35 Koesnoe, Hukum Adat Sebagai Suatu Model Hukum; Koesnoe, Hukum Adat, Dalam Alam Kemerdekaan Nasional Dan Persoalan Menghadapi Era Globalisasi. 
offer in the midst of the complex problems of Indonesian Law which are increasingly moving away from its goal of meeting the needs of society to provide justice. Substantively and real. Thus, if the direction of development and the development of Indonesian Law is still aimed at the philosophical objectives of the Law itself, namely creating order through the fulfillment of justice for all society, then significant and fundamental changes must be made in the paradigm of Indonesian Law so that Indonesian Law is immediately aware of its isolation for then immediately return to its original essence, to Customary Law because: "Customary law is Indonesian law and Indonesian law is customary law."

\section{Reference}

Abdul Kadir, Muhammad. "Hukum Dan Penelitian Hukum." Bandung: PT. Citra Aditya Bakti., 2015.

Aditya, Zaka, and Sholahuddin Al-Fatih. "STATE LIABILITY FOR VIOLATION OF CONSTITUTIONAL RIGHTS AGAINST INDIGENOUS PEOPLE IN FREEDOM OF RELIGION AND BELIEF." Brawijaya Law Journal 4, no. 1 (March 31,2017):29-58. https:// doi.org/10.21776/ub.blj.2017.004.01.02.

Aditya, Zaka Firma. "Romantisme Sistem Hukum Di Indonesia : Kajian Atas Konstribusi Hukum Adat Dan Hukum Islam Terhadap Pembangunan Hukum Di Indonesia." Jurnal Rechts Vinding: Media Pembinaan Hukum Nasional 8, no. 1 (2019): 37. https://doi.org/10.33331/rechtsvinding. v8i1.305.

Ahmad, Ansori. Sejarah Dan Kedudukan BW Di Indonesia. 1st ed. (Jakarta: Rajawali, 1986.

Apeldoorn, Van. Inleiding Tot De Studie van Het Nederlandse Recht. 1st ed. Jakarta: Pradnya Paramita, 1985.

Apple, James G, and Robert P. Deyling. "A Primer on the Civil Law System." In Federal Juducial Centre and International Judicial Relation Committee of Judicial Confrence of United State, 1. United State: Federal Juducial Centre and International Judicial Relation Committee of Judicial Confrence of United State, 2000.

Dewi, Ratna Winahyu Lestari. "PERANAN HUKUM ADAT DALAM PEMBANGUNAN DAN PEMBENTUKAN KITAB UNDANGUNDANG HUKUM PIDANA NASIONAL.” Perspektif 10, no. 3 (July 29, 2005): 265. https://doi.org/10.30742/perspektif.v10i3.271. 
H. Mustaghfirin. "Sistem Hukum Barat, Sistem Hukum Adat, Dan Sistem Hukum Islam Menuju Sebagai Sistem Hukum Nasional Sebuah Ide Yang Harmoni." Jurnal Dinamika Hukum, 11, no. 1 (2011): 92.

Hamzah, Andi. Asas-Asas Hukum Pidana. 1st ed. Jakarta: PT. Rinek Cipta, 2010. Huijbers, Theo. Filsafat Hukum Dalam Lintasan Sejarah. 1st ed. Yogyakarta: Kanisius, 1982.

Kemenristekdikti. "Undang-Undang Dasar Republik Indonesia 1945." Resntra Kemenristekdikti 2015-2019, 2015.

Koesnoe, Moh. Hukum Adat, Dalam Alam Kemerdekaan Nasional Dan Persoalan Menghadapi Era Globalisasi. 1st ed. Surabaya: Ubhara Press, 1996.

—. Hukum Adat Sebagai Suatu Model Hukum. 1st ed. Bandung: Mandar Maju, 1992.

Kompas. "Warga Miskin Tolak Raperda Ketertiban Umum.” Kompas. September 11, 2007.

Lukito, Ratno. Pergumulan Antara Hukum Islam Dan Adat Di Indonesia. 1st ed. Jakarta: INIS, 1998.

Mahmud Marzuki dan Peter Mahmud. "Penelitian Hukum,.” Jurnal Penelitian Hukum, 2011.

Orucu, Erin. "What Is a Mixed Legal System: Exclusion or Expansion." What Is a Mixed Legal System: Exclusion or Expansion 12, no. 1 (2008): 2.

Prodjodikoro, Wirjono. Tindak-Tindak Pidana Tertentu Di Indonesia. 1st ed. Bandung: PT Refika Aditama, 2008.

Rahardjo, Satjipto. Sisi-Sisi Lain Dari Hukum Di Indonesia. 1st ed. Jakarta: Kompas, 2003.

Rofiq, Ahmad. Pembaharuan Hukum Islam Di Indonesia. 1st ed. Yogyakarta: Gema Medua, 2001.

Rosmidah, Rosmidah. "Pengakuan Hukum, Hak Ulayat, Masyarakat Hukum Adat, Hambatan, Implementasinya." Inovatif, Jurnal Ilmu Hukum 2, no. 4 (2010).

Sahalessy, Jacoba. "PERAN LATUPATI SEBAGAI LEMBAGA HUKUM ADAT DALAM PENYELESAIAN KONFLIK ANTAR NEGERI DI KECAMATAN LEIHITU PROPINSI MALUKU.” SASI 17, no. 3 (September 30, 2011): 45. https://doi.org/10.47268/sasi.v17i3.364.

Salampessy, M. Yahdi. "The Leiden Legacy: Concepts of Law in Indonesia." Indonesia Law Review 4, no. 3 (December 1, 2014): 385. https://doi. org/10.15742/ilrev.v4n3.123. 
Shidarta. "Karakteristik Penalaran Hukum Dalam Konteks Indonesia." Universitas Parahyangan, 2004.

Soekanto, Soerjono. Masalah Kedudukan Dan Peranan Hukum Adat,. 1st ed. Jakarta: Academica, 1979.

Soekanto, Soerjono, and Sri Mamudji. Penelitian Hukum Normatif, Suatu Tinjauan Singkat.Jakarta : Raja Grafindo Persada, 2011.

Sulatriyono. "Penerapan Norma Dan Asas-Asas Hukum Adat Dalam Praktik Peradilan Perdata." Mimbar Hukum - Fakultas Hukum Universitas Gadjah Mada 24, no. 1 (2012): 25-40. https://doi.org/10.22146/jmh.16147.

Supusesa, Reimon. "Eksistensi Hukum Delik Adat Dalam Perspektif Pembaharuan Hukum Pidana Di Maluku Tengah.” Mimbar Hukum 24, no. 1 (2012): 41-54. https://doi.org/10.22146/jmh.16148.

Susanto, Anthon Freddy. Semiotika Hukum, Dekontruksi Teks Menuju Progresifitras Makna. 1st ed. Bandung: Refika Aditama, 2007.

Syamsudi, M. "Beban Masyarakat Adat Menghadapi Hukum Negara." Jurnal Hukum 15, no. 3 (2008): 338-51.

Wignjodipuro, Surojo. "Pengantar Dan Asas-Asas Hukum Adat." In Hukum Adat, 1st ed., 7. Bandung: Alumni, 1979. 
